\title{
Factors Influencing Organisational Buying Decisions in the Manufacturing Industry: Are Products and Services Procurement Different?
}

\author{
Dubravka Sinčić Ćorić
}

\begin{abstract}
The paper explores factors influencing services procurement decision-making of manufacturing companies, and compares it to factors influencing products procurement decision-making. Data were gathered by survey among manufacturing companies and analysed by using exploratory factor analysis. The comparison between factors influencing services procurement and factors influencing products procurement is made by content analysis. Results prove that six distinct factors influence manufacturing companies when making services procurement decisions: interdepartmental communication, trust in service provider, service provider flexibility, buyer's price sensitivity, top management support, and service provider competence. When compared to products procurement situation, it can be observed that some of the factors are influential in both purchasing situations, whereas other factors are not similarly important in both purchasing situations. The paper offers an insight to factors influencing buying decisions of manufacturing companies, that can help selling companies to better understand the differences in procurement processes of manufacturing companies in two buying situations: products procurement vs. services procurement.
\end{abstract}

Keywords: Organisational buying behaviour; Products procurement; Services procurement; Manufacturing companies; Factor analysis

JEL Classification: L6, L84, M31

\section{Introduction}

Organisational buyers devote significant amounts of money and time in procurement decision-making (Shabani-Naeeni \& Ghasemy Yaghin, 2021), and invest a considerable effort in the supplier relationship management, especially when the supply items

\footnotetext{
* Dubravka Sinčić Ćorić is at Faculty of Economics and Business, University of Zagreb, Zagreb, Croatia.
} 
are vital for operations or competences (Iyer, 1996). Due to fierce competition and constant market changes, purchasing and supplier selection became very challenging (Shabani-Naeeni \& Ghasemy Yaghin, 2021). Responsible procurement is especially important for manufacturing companies, as they usually spend from fifty to seventy-five percent of their incomes on buying industrial products and professional services (Lindgreen et al., 2013).

The business-to-business (B2B) marketing and purchasing literature offer a great number of papers on buying behaviour, and on the assessment and choice of suppliers (Large, 2017). The majority of research analyse supplier selection criteria (e.g. Enyinda, Dunu \& Bell-Hanyes, 2010; Ghymn \& Jaffe, 2004; Ho, Xu \& Dey 2010; $\mathrm{Ng}, 2010$ ), including latest interest in sustainable procurement (Maignan \& Thorne Mcalister, 2003; Igarashi, de Boer \& Magerholm Fet, 2013). However, these research often present diverse and inconsistent results (Bunn, 1994; Lewin \& Donthu, 2005). More to it, even though professional, or business (B2B) services are becoming more and more important for companies, the majority of B2B purchasing literature deals with the purchase of industrial products in relation to the purchase of services (Ellram et al., 2007; Tate et al., 2017)).

This paper contributes to the organisational buying behaviour literature by studying and comparing buying decision factors of manufacturing companies in two different buying situations: (1) when deciding about buying an industrial product, and (2) in professional service procurement situation. Therefore, two main research questions of this study are: (1) "What are the most important factors influencing organisational buying decisions in services procurement?", and (2) "Are there any differences between factors influencing organisational buying decisions in service procurement in relation to factors influencing products procurement?'. Researchers and practitioners came to an agreement that organisational buyers' decision-making varies across different buying situations, which leads to the conclusion that different groups of factors should be studied for different settings (Bunn, 1993; Leonidou, 2005). Previous studies proved that there are differences between purchasing industrial products in relation to purchasing services, but Smeltzer and Ogden (2002, cited in Sonmez \& Moorhouse, 2010) point that only a small number of studies is conducted to study exactly the differences between purchasing industrial products and services.

The paper follows the previous research made by Sinčić Ćorić et al. (2017), whose research identifies factors influencing products procurement decisions of manufacturing companies operating in Croatia.

A paper by Sinčić Ćorić et al. (2017) followed the sequential transformative design. Their items and scales were developed from the literature, and enhanced by in-depth interviews with manufacturing companies' procurement representatives. In this study, the similar procedure has been repeated. The original (product-oriented) questionnaire was adapted for the service setting, and validated through in-depth interviews with manufacturing companies' representatives - service procurement man- 
agers. The data were gathered from the same sample, which enables the comparison between the results. The comparison is made between the identified set of variables in two different buying situations (products vs. services procurement), which represents a contribution of this paper. The paper has a practical implication, as well. It can provide an insight in different factors that affect B2B buyers in different buying situations (product vs. services procurement), and thus help selling companies' representatives to better understand their B2B customers.

The remainder of the paper is structured as follows. A review of the factors influencing B2B buying behaviour, and specifics of B2B services procurement from the literature are presented in the second section. A research methodology is described in the third section, followed by results in the fourth section. The paper ends with discussion and conclusions.

\section{Literature review}

\section{Organisational buying behaviour}

The organisational buying behaviour was for many years characterized by a lack of research studies. Fundamental scientific papers regarding organisational buying behaviour date back to the sixties and seventies of the twentieth century. For almost twenty years after there were no significant contributions to the field. During the eighties of the twentieth century, research on organisational buying behaviour has been increased. From that time onwards, diverse variables influencing organisational buying decision approaches, as well as typologies of this approaches, have been proposed (i.e. Bunn, 1993; Moon \& Tikoo, 2002; Sinčić Ćorić et al., 2017). Wind, one of the first academics in the area of organisational buying behaviour, calls researchers to revise models in business and industrial marketing, due to changes in business environment, especially technology and change in business models. He proposes "a broader thinking that can embrace both consumer and industrial markets and the changing nature of relationship across firms, such as outsourcing and networked relationships" (Wind, 2006, 480).

Organisational buying behaviour researchers examined multiple variables influencing buyer's buying behaviour. Sinčić Ćorić et al. (2017) summarize them into four groups of factors: (1) general environmental factors, such as external (economic, political or competitive environment and internal ones (organisational culture, strategy and goals or buying centre dynamics), (2) contextual factors, such as exogenous variables (economic crisis) and endogenous variables (company's transformation), (3) situational factors, such as perceived risk information availability and reliability (first task, rebuy or strait rebuy) and importance of a certain purchase (routine purchase, procedural problems or organisational expectations), and (4) general characteristics 
of a buyer, (size, main activity, market orientation or ownership structure), as well as its behavioural patterns (organisational memory or learning orientation) and strategic orientation (value-oriented or cost-oriented purchasing).

\section{Factors influencing organisational buying decision-making}

"Industrial goods can be divided into three broad categories: entering goods, foundation goods, and facilitating goods" (Hutt \& Speh, 2010, 22). Entering goods include raw materials and manufactured materials and components, and become a part of the final product. Foundation goods are capital items that include installations and accessory equipment, while facilitating goods are products and services that enable organisational operations (Sinčić, 2004; Hutt \& Speh, 2010).

Business services encompass "activities added to or included in the final offering, such as manufacturing and product services" (Blumberg 2003, in Nordin \& Angdal, $2008,5)$, as well as "those indirect services used by the firm itself, such as information technology (IT) and business consulting" (Nordin \& Angdal, 2008, 5). They can be split into: professional services, like market research, legal aid, or advertising or taxation consultancy; and other (generic) services such as maintenance or cleaning. Due to externalization, business services are nowadays more and more globally sourced (Nordin \& Angdal, 2008).

The increasing importance and perceived risk of professional service purchasing have put higher expectations on the purchasing function in organisations (Pemer et al., 2014). Pemer et al. (2014) conclude that the purchasing of professional services differs to a large extent from and is perceived as more complex and difficult than the purchasing of products. These complexities are associated to their specific characteristics: they are intangible, abstract and dependable on the buyer-supplier interaction. Sonmez and Moorhouse (2010) observe that efficient and effective purchasing of professional services is critical for both buyers and service providers. That is why it is essential to understand how, and following which decision criteria, companies purchase professional services, as well as to which decision criteria they assign the greatest importance when choosing the professional service providers.

A notable number of research have been conducted in the area of factors influencing organisational buying decision. For instance, Enyinda et al. (2010) revealed that these factors are: quality, cost, regulatory compliance, service reliability, risk management, supplier profile, and green purchasing; Shil (2009) numbers: performance, satisfaction, and experience; while Ng (2010) states: supplier criteria, service performance criteria, product performance criteria, and cost criteria.

The variety of factors affecting organisational purchasing decision making is also the consequence of different industries that served as a contextual framework for research. 
Sonmez and Moorhouse (2010) point out that, even though decision criteria used for choosing service providers may be analogous to that of product supplier selection, the definition of criteria and sub criteria as well as significance assigned to these criteria may differ. Therefore, further research that may contribute with other views in this area are justified.

\section{Methodology}

\section{Sample, data collection and measurement scale}

The data for this study were gathered from a survey conducted among Croatian manufacturing companies during 2018. The questionnaire was sent to the same sample that participated in the research presented by Sinčić Ćorić et al. (2017): 544 companies registered in the Croatian manufacturing industry (section C according to NACE Rev. 2), in the Croatian Chamber of Economy online database. Key informants were procurement managers. In total 81 questionnaires were completed and returned, producing a return rate of $14.9 \%$. A summary of sample characteristics is presented in Table 1.

Table 1: Sample characteristics, $n=81$

\begin{tabular}{|l|c|}
\hline \multicolumn{2}{|l|}{ Percentage } \\
\hline Main activity & 14.8 \\
\hline Manufacture of food products & 1.2 \\
\hline Manufacture of beverages & 2.5 \\
\hline Manufacture of textile & 1.2 \\
\hline Manufacture of wearing apparel & 1.2 \\
\hline Manufacture of leather and related products & 4.9 \\
\hline $\begin{array}{l}\text { Manufacture of wood and products of wood and cork, except furniture; manufacture of } \\
\text { articles of straw and plaiting materials }\end{array}$ & 1.2 \\
\hline Manufacture of paper and paper products & 1.2 \\
\hline Printing and reproduction of recorded media & 1.2 \\
\hline Manufacture of coke and refined petroleum products & 6.2 \\
\hline Manufacture of chemicals and chemical products & 2.5 \\
\hline Manufacture of basic pharmaceutical products and pharmaceutical preparations & 6.2 \\
\hline Manufacture of rubber and plastic products & 7.4 \\
\hline Manufacture of other non-metallic mineral products & 3.7 \\
\hline Manufacture of basic metals & 11.1 \\
\hline Manufacture of fabricated metal products, except machinery and equipment & 3.7 \\
\hline Manufacture of computer, electronic and optical products & 3.7 \\
\hline Manufacture of electrical equipment & \\
\hline
\end{tabular}




\begin{tabular}{|c|c|}
\hline & Percentage \\
\hline Manufacture of machinery and equipment n.e.c. & 3.7 \\
\hline Manufacture of furniture & 6.2 \\
\hline Other manufacturing & 16.0 \\
\hline \multicolumn{2}{|l|}{ Ownership } \\
\hline Dominantly private Croatian ownership & 70.4 \\
\hline Dominantly private foreign ownership & 23.5 \\
\hline Dominantly state/public ownership & 2.5 \\
\hline No answer & 3.7 \\
\hline \multicolumn{2}{|l|}{ Number of employees } \\
\hline From 10 to 49 & 4.9 \\
\hline From 50 to 249 & 60.5 \\
\hline 250 and more & 34.6 \\
\hline
\end{tabular}

Source: research data

The first study conducted by Sinčić Ćorić et al. (2017) was designed following the sequential transformative design. Based on literature review, a pool of different organisational buying behaviour constructs and corresponding items, was verified with manufacturing companies' procurement managers. Based on these inputs, a questionnaire was developed and tested. In this study, a similar procedure was undertaken. Literature review, and in-depth interviews with service procurement managers confirmed that the original product-oriented questionnaire can be adapted to the service context, by changing items' wording - replacing "product" with "service". This facilitated that two sets of data - the one concerning buying industrial products, and the other related to the professional service procurement, can be compared.

The adapted questionnaire consisted of 62 items linked to the different aspects of service procurement behaviour. All items were measured on a seven-point Likerttype scale, where 1 denotes "strongly disagree" and 7 denotes "strongly agree". Questions about the company's demographics were also included in the questionnaire.

\section{Data analysis procedure}

The data were analysed by principal component factor analysis. Initial factor analysis was employed on 62 variables (items). Items with loadings higher than 0.5 on more than one factor and items with loadings lower than 0.5 on all factors were not included in further analysis. A final set of 20 items was further analysed. 


\section{Research results: Factors influencing organisational buying decision-making in service procurement}

Analysis of the correlation matrix discloses that all variables have at least one correlation coefficient with an absolute value greater than 0.3 (at the $1 \%$ significance level). All measures of sampling adequacy values were greater than 0.5 , approving further application of factor analysis.

By following the Kaiser criterion, six factors, explaining $78.6 \%$ of the total variance of the 20 analysed variables were extracted. The initial factor matrix was difficult to interpret, therefore varimax rotation was used to transformed it into a simpler and easier to interpret matrix. All factor loadings are larger than 0.5.

Factors are labelled as follows: (1) interdepartmental communication, (2) trust in service provider, (3) service provider flexibility, (4) buyer price sensitivity, (5) top management support, (6) service provider competence. Factor 1 "Interdepartmental/ cross-functional communication" describes how employees of the buying company interact and communicate during procurement process. Factor 2 "Trust in service provider" refers to trust in service provider, built on previous experience or long-term relationships. Factor 3 "service provider flexibility" is associated to characteristics of service providers, describing if they are flexible enough to customize their delivery procedures and invest in new equipment. Factor 4 "Buyer's price sensitivity" represents how does buying company perceive price when buying services. Factor 5 "Top management support" describes how important procurement is, both as an activity and function in the buying organisation. Factor 6 "Service provider competence" relates to the characteristics of service providers, defining their competence, technical skills and speed in delivering services. (Table 2.)

Table 2: Factors influencing organisational buying decision-making in service procurement, $\mathrm{n}=81$

\begin{tabular}{|l|c|}
\hline Factors and variables (items) & $\begin{array}{c}\text { Factor } \\
\text { loadings }\end{array}$ \\
\hline Factor 1: Buyer's interdepartmental/cross-functional communication & $\mathbf{0 , 8 8}$ \\
\hline Various functional departments in our company interact during the purchasing process. & $\mathbf{0 , 8 9}$ \\
\hline $\begin{array}{l}\text { In our company, there is a tradition of good communication between departments that directly } \\
\text { or indirectly participate in the purchasing process. }\end{array}$ & $\mathbf{0 , 8 6}$ \\
\hline $\begin{array}{l}\text { In our company, managers of different departments/functions are expected to share key } \\
\text { information that is essential for successful purchasing. }\end{array}$ & $\mathbf{0 , 7 7}$ \\
\hline $\begin{array}{l}\text { In our company, more people are involved in the decisions about procurement of strategically } \\
\text { important services. }\end{array}$ & \begin{tabular}{l}
$\mathbf{0 , 6 9}$ \\
\hline Factor 2: Trust in service provider \\
\hline $\begin{array}{l}\text { In our purchasing decision-making process service providers with whom we have had previous } \\
\text { experience are assessed more favourably than those who are unknown to us. }\end{array}$
\end{tabular} \\
\hline
\end{tabular}




\begin{tabular}{|c|c|}
\hline We seldom change providers of services that are strategically important to us. & 0,74 \\
\hline The trust in service provider play an important role in our decision-making. & 0,74 \\
\hline We always contact trustful providers when purchasing services of a great value. & $\mathbf{0 , 8 3}$ \\
\hline We asses more favourably service providers with whom we have long-term relationship. & $\mathbf{0 , 9 2}$ \\
\hline \multicolumn{2}{|l|}{ Factor 3: Service provider flexibility } \\
\hline $\begin{array}{l}\text { We cooperate only with those service providers who are willing to change their delivery } \\
\text { procedures for us. }\end{array}$ & $\mathbf{0 , 9 3}$ \\
\hline $\begin{array}{l}\text { We cooperate only with those service providers who are willing to invest in tools and } \\
\text { equipment for us. }\end{array}$ & $\mathbf{0 , 9 3}$ \\
\hline \multicolumn{2}{|l|}{ Factor 4: Buyer's price sensitivity } \\
\hline Price is the most important factor in our purchasing. & $-0,92$ \\
\hline We always choose the suppliers that offer the lowest price. & $-\mathbf{0 , 8 9}$ \\
\hline \multicolumn{2}{|l|}{ Factor 5: Top management support } \\
\hline In this company, purchasing is considered a vital part of our corporate strategy. & $\mathbf{0 , 8 5}$ \\
\hline Top management is supportive of our efforts to improve the purchasing department. & $\mathbf{0 , 7 6}$ \\
\hline Purchasing employees' views are considered critical in most top managers' eyes. & $\mathbf{0 , 8 8}$ \\
\hline \multicolumn{2}{|l|}{ Factor 6: Service provider competence } \\
\hline Our company co-operates with service providers who really care about our success. & $\mathbf{0 , 7 4}$ \\
\hline $\begin{array}{l}\text { Purchase is most likely to be made from those service providers who are ready to adjust to our } \\
\text { requirements. }\end{array}$ & 0,60 \\
\hline Technical competence of service provider is always considered. & $\mathbf{0 , 8 1}$ \\
\hline Speed and the punctuality of delivery are important factors that affect our selection of a supplier. & $\mathbf{0 , 6 9}$ \\
\hline
\end{tabular}

Source: research data, items adapted from the original questionnaire by Sinčić Ćorić et al. (2017)

\section{Discussion and conclusions}

The aim of this study was to explore factors influencing services procurement behaviour of manufacturing companies, and compare them with those influencing products procurement behaviour. The analysis proves that there are six unique factors that influence services procurement organisational decision-making. These are: (1) interdepartmental communication, (2) trust in service provider, (3) service provider flexibility, (4) buyer's price sensitivity, (5) top management support, and (6) service provider competence. Previous study (by Sinčić Ćorić et al., 2017) also recognized six distinctive factors affecting products procurement organisational decision-making: "(1) supplier flexibility, (2) supplier reliability, (3) interdepartmental communication, (4) top management support, (5) routine purchases, and (6) buyer's price sensitivity" (p. 232-233).

As can be seen from Table 3. some factors are (almost) similar for both buying situations. These are factors "interdepartmental communication", "top management 
support", and "buyer's price sensitivity". Factor "service provider flexibility" to some extant relate to the factor "supplier flexibility" from previous study. That means that some items from factor "supplier flexibility" from previous study fell out in this study, and were not perceived important within new factor. Factor "service provider competence" consist of two similar items from previous factor "supplier reliability", but three original items were substituted with two new ones. New items relate to technical competence and firm relationship with service provider.

Table 3: Comparison of factors influencing organisational decision-making in services procurement vs. products procurement

\begin{tabular}{|c|c|}
\hline CE & $\begin{array}{l}\text { ACTORS INFLUENCING PR } \\
\text { ROCUREMENT }\end{array}$ \\
\hline $\begin{array}{l}\text { Factor } 1 \text { (Cronbach alpha }=\mathbf{0 . 9 2} \text { ) } \\
\text { Buyer's interdepartmental/cross-functional } \\
\text { communication } \\
\text { - Various functional departments in our company } \\
\text { interact during the purchasing process. } \\
\text { - In our company, there is a tradition of good } \\
\text { communication between departments that directly or } \\
\text { indirectly participate in the purchasing process. } \\
\text { - In our company, managers of different departments/ } \\
\text { functions are expected to share key information that } \\
\text { is essential for successful purchasing. } \\
\text { - In our company, more people are involved in } \\
\text { the decisions about procurement of strategically } \\
\text { important services. }\end{array}$ & $\begin{array}{l}\text { Factor } 3 \text { (Cronbach alpha = 0.845) } \\
\text { Buyer's interdepartmental/cross-functional } \\
\text { communication } \\
\text { - Various functional departments in our company } \\
\text { interact during the purchasing process. } \\
\text { - In our company, there is a tradition of good } \\
\text { communication between departments that directly or } \\
\text { indirectly participate in the purchasing process. } \\
\text { - In our company, managers of different departments/ } \\
\text { functions are expected to share key information that } \\
\text { is essential for successful purchasing. } \\
\text { - Our company is organized in such a way that } \\
\text { information important for purchasing decisions are } \\
\text { available and delivered without any restrictions. }\end{array}$ \\
\hline $\begin{array}{l}\text { Factor } 2 \text { (Cronbach alpha = 0.84) } \\
\text { Trust in service provider } \\
\text { - In our purchasing decision-making process service } \\
\text { providers with whom we have had previous } \\
\text { experience are assessed more favourably than those } \\
\text { who are unknown to us. } \\
\text { - We seldom change providers of services that are } \\
\text { strategically important to us. } \\
\text { - The trust in service provider play an important role } \\
\text { in our decision-making. } \\
\text { - We always contact trustful providers when } \\
\text { purchasing services of a great value. } \\
\text { - We asses more favourably service providers with } \\
\text { whom we have long-term relationship. }\end{array}$ & $\begin{array}{l}\text { Factor } \mathbf{5} \text { (Cronbach alpha = 0.788) } \\
\text { Routine purchase } \\
\text { - When we purchase routine products (i.e. office or } \\
\text { cleaning utensils) we rarely ask for new information } \\
\text { - When we purchase routine products (i.e. office } \\
\text { or cleaning utensils) we rarely search for new } \\
\text { suppliers. } \\
\text { - In our purchasing decision-making process suppliers } \\
\text { with whom we have had previous experience are } \\
\text { assessed more favourably than those who are } \\
\text { unknown to us. }\end{array}$ \\
\hline
\end{tabular}




\section{FACTORS INFLUENCING SERVICE PROCUREMENT}

Factor $3($ Cronbach alpha $=\mathbf{0 . 9 1})$

Service provider flexibility

- We cooperate only with those service providers who are willing to change their delivery procedures for us.

- We cooperate only with those service providers who are willing to invest in tools and equipment for us.

\section{FACTORS INFLUENCING PRODUCT} PROCUREMENT

Factor $1($ Cronbach alpha $=\mathbf{0 . 9 1 3})$

Supplier flexibility

- We cooperate only with those service providers who are willing to change their delivery procedures for us

- We cooperate only with those service providers who are willing to invest in tools and equipment for us.

- We cooperate only with those suppliers who are willing to customize their products for us.

- We cooperate only with those suppliers who are willing to change their production processes for us.

- We cooperate only with those suppliers who are willing to change their inventory procedures for us.

Factor $4($ Cronbach alpha $=\mathbf{0 . 8 0})$

Buyer's price sensitivity

- Price is the most important factor in our purchasing decision.

- We always choose the suppliers that offer the lowest price.

Factor $5($ Cronbach alpha $\mathbf{= 0 . 8 8})$

Top management support

- In this company, purchasing is considered a vital part of our corporate strategy.

- Top management is supportive of our efforts to improve the purchasing department.

- Purchasing employees' views are considered critical in most top managers' eyes

Factor $6($ Cronbach alpha $=\mathbf{0 . 8 1})$

Service provider competence

- Purchase is most likely to be made from those service providers who are ready to adjust to our requirements.

- Speed and the punctuality of delivery are important factors that affect our selection of a supplier.

- Our company co-operates with service providers who really care about our success.

- Technical competence of service provider is always considered.

\section{Factor $6($ Cronbach alpha $=\mathbf{0 . 6 8 1})$}

Buyer's price sensitivity

- Price is the most important factor in our purchasing decision.

- We always choose the suppliers that offer the lowest price.

Factor $4($ Cronbach alpha $=\mathbf{0 . 8 6 2})$

Top management support

- In this company, purchasing is considered a vital part of our corporate strategy.

- Top management is supportive of our efforts to improve the purchasing department.

- Purchasing's views are considered critical in most top managers' eyes

Factor $2($ Cronbach alpha $=\mathbf{0 . 8 1 2})$

Supplier reliability

- Purchase is most likely to be made from those suppliers who are ready to adjust to our requirements.

- Speed and the punctuality of delivery are important factors that affect our selection of a supplier.

- Our company makes good use of IT to exchange information with suppliers.

- Only reliable companies can be our suppliers.

- When we make strategic purchases, we cooperate only with those suppliers who can deliver the required quantity in due time.

Source: current study and Sinčić et al. (2017)

Note: underlined items are new ones; italic items are from previous research (not present in the current study); white boxes denote totally new (different) factor; light grey boxes denote similar factors; dark grey denotes both similarities and changes in factors

However, factor "routine purchase" did not yield significant loading in services procurement decision-making. Quite a contrary, factor "trust in service provider", containing one item from previous factor "routine purchase" showed greater impor- 
tance for services procurement decision-making. Companies report that they assess more favourably service providers with whom they have had previous experience, who have a reputation of being trustful, and with whom they have long-term relationship. More to it, they say that they are reluctant to change service providers if they are strategically important to them. It could be said that the item "The trust in service provider play an important role in our decision-making" summarizes the essence of all items within this factor. Items in this factor clearly depicts that services procurement decision-making is specific. This is primarily due to the risk organisational buyers perceive when choosing service provider, which is, due to intangibility and simultaneous production and consumption of services (Bienstock \& Royne, 2007), greater than in products procurement situations. Having trust in their service provider may diminish that perceived risk.

To summarize, factors related to service provider's flexibility, competence and trustfulness make a difference between products procurement and services procurement decision-making. They can not only lower the buyer's perceived purchasing risk, but they are considered as an important means of dealing with dynamic, complex, and competitive environment (Chan et al., 2009). Previous studies on products buying situations proved the importance of supplier flexibility (e.g., Lehmann and O'Shaughnessy, 1974; Enyinda et al., 2010). Kraljic specifically emphasize the importance of supplier flexibility in the strategic products purchase situation (Kraljic, 1983). So, to go back to Sonmez and Moorhouse (2010), who said that, even though decision criteria used for choosing service providers and product suppliers may be similar, the definition of criteria and sub criteria as well as importance assigned to these criteria may be different. This study confirms their conclusion.

Presented findings contribute to organisational buying behaviour literature. Although the research has been conducted in Croatia, a small transitional country, the fact is that there are many global companies operating in this market, as well as that B2B business has been globalized for many years. That means that certain procurement practices and standards are similar, regardless of the country's borders. Having that said, the results might be generalized and applicable to other manufacturing industries, especially those operating in other small transitional countries.

There are several managerial implications of this study. The results point that, although some of the factors influencing organisational buying decision-making are similar, there are differences among other factors in observed buying situations: products' procurement vs. services' procurement. It is important for suppliers/service providers to recognize and understand which factors are critical for specific situation. That will help them to adjust their selling approaches and strategies.

While interpreting the results of this study, some limitations should be taken into consideration. The study was conducted in one country, on a relatively small sample of manufacturing companies. Application of both instruments in other industries and countries would provide more accurate conclusions. Regardless of these limits, the 
results of this study provide valuable review of factors and their structures influencing manufacturing companies' buying behaviour, in two different buying situations: products procurement in relation to services procurement.

In future studies it would be useful to examine how this factors influence specific buying approach in services procurement. More to it, it would be useful to conduct a longitudinal study on this particular sample, in order to see whether the structure and importance of different factors change over time. Finally, there is still an open question whether these factors play (equally) important role in various industries and countries.

\section{REFERENCES}

Bienstock, C.C.\& Royne, M.B. (2007). The differential value of information in industrial purchasing decisions: Applying an economics of information framework. International Journal of Physical Distribution \& Logistics Management, 37(5), 389-408. DOI: 10.1108/09600030710758446.

Bunn, M.D. (1993). Taxonomy of buying decision approaches. Journal of Marketing. 57(1), 38-56. DOI: 10.1177/002224299305700103.

Bunn, M.D. (1994). Key aspects of organizational buying: conceptualization and measurement. Journal of the Academy of Marketing Science. 22(2), 160-169. DOI: 10.1177/0092070394222005.

Chan, F.T.S., Bhagwat, R. \& Wadhwa, S. (2009). Study on suppliers' flexibility in supply chains: is real-time control necessary?. International Journal of Production Research. 47(4), 965-987. DOI: $10.1080 / 00207540701255917$.

Ellram, L. M., Tate, W. L. \& Billington, C. (2007). Service supply management: The next frontier for improved organizational performance. California Management Review. 49(4), 44-66. DOI: $10.2307 / 41166405$.

Enyinda, C.I., Dunu, E. \& Bell-Hanyes, J. (2010). A model for quantifying strategic supplier selection: evidence from a generic pharmaceutical firm supply chain. International Journal of Business, Marketing, and Decision Sciences. 3(2), 25-44.

Ghymn, K.I. \& Jaffe, E.D. (2004). Importer vendor choice behaviour. Journal of Global Marketing. 17(1), 5-22. DOI: 10.1300/J042v17n01_02.

Ho, W., X. Xu \& P. Dey. 2010. Multi-Criteria Decision Making Approaches for Supplier Evaluation and Selection: A Literature Review. European Journal of Operational Research 202(1), 16-24. DOI: 10.1016/j.ejor.2009.05.009.

Hutt, M. D. \& Speh, T. W. (2010). Business Marketing Management: B2B (10th ed). Australia: South-Western, Cengage Learning

Igarashi, M., L. de Boer \& A. Magerholm Fet (2013). What Is Required for Greener Supplier Selection? A Literature Review and Conceptual Model Development. Journal of Purchasing and Supply Management 19(4), 247-263. DOI: 10.1016/j.pursup.2013.06.001.

Iyer, G. R. (1996). Strategic decision making in industrial procurement: implications for buying decision approaches and buyer-seller relationships. Journal of Business \& Industrial Marketing. 11(3/4), 80-93. DOI: 10.1108/08858629610125487.

Kraljic, P. (1983). Purchasing must become supply management. Harvard Business Review. 61(5), 109-117.

Large, R. O. (2017). Who buys logistics services? Organisational and occupational issues, Supply Chain Forum: An International Journal. 18(1), 7-12, DOI: 10.1080/16258312.2017.1281076 
Lehmann, D.R. \& O'Shaughnessy, J. (1974). Difference in attribute importance for different industrial products. Journal of Marketing, 38(2), 36-42. DOI: 10.2307/1250195.

Leonidou, L. C. (2005). Industrial buyer's influence strategies: buying situations differences, Journal of Business and Industrial marketing. 20(1), 33-42. DOI: 10.1108/08858620510576775.

Lewin, J.E. \& Donthu, N. (2005). The influence of purchase situation on buying center structure and involvement: a select meta-analysis of organizational buying behavior research. Journal of Business Research. 58(10), 1381-1390. DOI: 10.1016/j.jbusres.2004.09.004.

Lindgreen, A., Vanhamme, J., van Raaij, E.M. \& Johnston, W.J. (2013). Go configure: the mix of purchasing practices to choose for your supply base. California Management Review. 55(2), 72-96. DOI: $10.1525 / \mathrm{cmr} .2013 .55 .2 .72$.

Maignan, I. \& Thorne Mcalister, D. (2003). Socially Responsible Organizational Buying: How Can Stakeholders Dictate Purchasing Policies?. Journal of Macromarketing. 23(2), 78-89. DOI: $10.1177 / 0276146703258246$.

Moon, J. \& Tikoo, S. (2002). Buying decision approaches of organizational buyers and users. Journal of Business Research. 55(4), 293-299. DOI: 10.1016/S0148-2963(00)00155-7.

$\mathrm{Ng}$, E. (2010). Understanding B2B supplier selection relationships: the case of Taiwan agribusinesses. Journal of Business-to-Business Marketing. 17(2), 149-172.DOI: 10.1080/10517120902762492.

Nordin, F. \& Agndal, H. (2008). Business Service Sourcing: A Literature Review and Agenda

for Future Research. International Journal of Integrated Supply Management. 4(3/4), 378-405. DOI: 10.1504/IJISM.2008.020760.

Pemer, F., Werr, A. \& Bianchi, M. (2014). Purchasing professional services: A transaction cost view of the antecedents and consequences of purchasing formalization. Industrial Marketing Management. 43(5), 840-849. DOI: 10.1016/j.indmarman.2014.04.009.

Shil, N.C. (2009). A case on vendor selection methodology: an integrated approach. Journal of Transport and Supply Chain Management. 3(1), 80-95. DOI: 10.4102/jtscm.v3i1.56.

Sinčić, D. (2004). Marketing poslovnih tržišta" (Business-to-business marketing), in J. Previšić, Đ. Ozretić Došen (Eds.), Marketing (pp. 415-440). Zagreb: Adverta

Sinčić Ćorić, D., Anić, I.-D., Piri Rajh, S., Rajh, E. \& Kurnoga, N. (2017). Organizational buying decision approaches in manufacturing industry: developing measures and typology. Journal of Business \& Industrial Marketing. 32(2), 227-237. DOI: 10.1108/JBIM-10-2014-0214.

Shabani-Naeeni, F. \& Ghasemy Yaghin, R. (2021). Incorporating data quality into a multi-product procurement planning under risk. Journal of Business \& Industrial Marketing, ahead-of-print DOI: 10.1108/JBIM-02-2020-0108.

Sonmez, M. \& Moorhouse, A. (2010). Purchasing professional services: which decision criteria?. Management Decision. 48(2), 189-206. DOI: 10.1108/00251741011022572.

Tate, W.L., Ellram, L.M. \& Schmelzle, U. (2017). A little help from my friends: how purchasing gains influence in complex business-to-business services: the case of legal. Journal of Business \& Industrial Marketing. 32(2), 206-217. DOI: 10.1108/JBIM-01-2015-0006.

Wind, Y. (2006). Blurring the lines: is there a need to rethink industrial marketing. Journal of Business \& Industrial Marketing. 21(7), 474-481. DOI: 10.1108/08858620610708975. 